\title{
Effect of repeat unit structure and molecular mass of lactic acid bacteria hetero- exopolysaccharides on binding to milk proteins
}

Birch, Johnny; HarĐarson, HörĐur Kári; Khan, Sanaullah; Van Calsteren, Marie-Rose; Ipsen, Richard; Garrigues, Christel; Almdal, Kristoffer; Abou Hachem, Maher ; Svensson, Birte

\section{Published in:}

Carbohydrate Polymers

Link to article, DOI:

10.1016/j.carbpol.2017.08.055

Publication date:

2017

Document Version

Peer reviewed version

Link back to DTU Orbit

Citation (APA):

Birch, J., HarĐarson, H. K., Khan, S., Van Calsteren, M-R., Ipsen, R., Garrigues, C., Almdal, K., Abou Hachem, M., \& Svensson, B. (2017). Effect of repeat unit structure and molecular mass of lactic acid bacteria heteroexopolysaccharides on binding to milk proteins. Carbohydrate Polymers, 177, 406-414. https://doi.org/10.1016/j.carbpol.2017.08.055

\section{General rights}

Copyright and moral rights for the publications made accessible in the public portal are retained by the authors and/or other copyright owners and it is a condition of accessing publications that users recognise and abide by the legal requirements associated with these rights.

- Users may download and print one copy of any publication from the public portal for the purpose of private study or research.

- You may not further distribute the material or use it for any profit-making activity or commercial gain

- You may freely distribute the URL identifying the publication in the public portal 


\section{Effect of repeat unit structure and molecular mass of lactic acid}

\section{bacteria hetero-exopolysaccharides on binding to milk proteins}

Johnny Birch $^{\mathrm{a}}$, Hörður Kári Harðarson ${ }^{\mathrm{a}}$, Sanaullah Khan ${ }^{\mathrm{b}}$, Marie-Rose Van Calsteren ${ }^{\mathrm{c}}$, Richard Ipsen ${ }^{\mathrm{d}}$, Christel Garrigues $^{\mathrm{e}}$, Kristoffer Almdal ${ }^{\mathrm{b}}$, Maher Abou Hachem ${ }^{\mathrm{a}}$, Birte Svensson ${ }^{\mathrm{a}}{ }^{*}$

${ }^{a}$ Enzyme and Protein Chemistry, Department of Biotechnology and Biomedicine, Technical University of Denmark, Elektrovej, building 375, DK-2800 Kgs. Lyngby, Denmark

${ }^{b}$ Department of Micro- and Nanotechnology, Technical University of Denmark, Produktionstorvet, building 423, DK-2800 Kgs. Lyngby, Denmark

'Saint-Hyacinthe Research and Development Centre, Agriculture and Agri-Food Canada, 3600 Casavant Boulevard West, Saint-Hyacinthe, Quebec J2S 8E3, Canada

${ }^{\mathrm{d} D e p a r t m e n t}$ of Food Science, University of Copenhagen, Rolighedsvej 26, DK-1958 Frederiksberg C, Denmark

${ }^{\text {e}}$ CED-Discovery, Chr Hansen A/S, DK-2970 Hørsholm, Denmark

*Corresponding author. Tel.: +45 4525 2740; fax: +45 4588 6307. E-mail addresses: bis@bio.dtu.dk (B. Svensson), birch@bio.dtu.dk (J. Birch), hordurkari@gmail.com (H.K. Harðarson), sank@nanotech.dtu.dk (S. Khan), Marie-Rose.VanCalsteren@AGR.GC.CA (M.R. Van Calsteren), ri@food.ku.dk (R. Ipsen), christel.garrigues@gmail.com (C. Garrigues), kral@nanotech.dtu.dk (K. Almdal), maha@bio.dtu.dk (M. Abou Hachem). 


\title{
Highlights
}

- Surface plasmon resonance was used to characterize HePS-milk protein interactions

- Binding affinity depends on HePS size, repeat structure, $\mathrm{pH}$ and ionic strength

- Heat-treatment of $\beta$-lactoglobulin dramatically increased HePS binding capacity

\begin{abstract}
Interactions of exopolysaccharides and proteins are of great importance in food science, but complicated to analyze and quantify at the molecular level. A surface plasmon resonance procedure was established to characterize binding of seven structure-determined, branched heteroexopolysaccharides (HePSs) of 0.14-4.9 MDa from lactic acid bacteria to different milk proteins ( $\beta$ casein, $\kappa$-casein, native and heat-treated $\beta$-lactoglobulin) at $\mathrm{pH}$ 4.0-5.0. Maximum binding capacity $\left(\mathrm{RU}_{\max }\right)$ and apparent affinity $\left(K_{\mathrm{A}, \mathrm{app}}\right)$ were HePS- and protein-dependent and varied for example 10and 600-fold, respectively, in the complexation with native $\beta$-lactoglobulin at $\mathrm{pH} 4.0$. Highest $\mathrm{RU}_{\max }$ and $K_{\mathrm{A} \text {,app }}$ were obtained with heat-treated $\beta$-lactoglobulin and $\beta$-casein, respectively. Overall, $\mathrm{RU}_{\max }$ and $K_{\mathrm{A} \text {,app }}$ decreased 6- and 20-fold, respectively, with increasing $\mathrm{pH}$ from 4.0 to 5.0. $K_{\mathrm{A} \text {,app }}$ was influenced by ionic strength and temperature, indicating that polar interactions stabilize HePS-protein complexes. HePS size as well as oligosaccharide repeat structure, conferring chain flexibility and hydrogen bonding potential, influence the $K_{\mathrm{A} \text {,app. }}$.
\end{abstract}

Keywords: 
Hetero-exopolysaccharides (HePSs), $\beta$-lactoglobulin, $\beta$ - and $\kappa$-casein, binding parameters, surface plasmon resonance (SPR), dynamic light scattering (DLS)

\section{Abbreviations:}

BCN, $\beta$-casein; BLG, $\beta$-lactoglobulin; DLS, dynamic light scattering; EPS, exopolysaccharide; Gal, galactose; GalNAc, $N$-acetylgalactosamine; Glc, glucose; GlcNAc, $N$-acetylglucosamine; hBLG, heattreated BLG; HePS, hetero-exopolysaccharide; HoPS, homo-exopolysaccharide; KCN, к-casein; LAB, lactic acid bacteria; nBLG, native BLG; pI, isoelectric point; Pyr, pyruvate; Rha, rhamnose; SEC, sizeexclusion chromatography; SNR, signal-to-noise ratio; SPR, surface plasmon resonance.

\section{Introduction}

Homo- and hetero-exopolysaccharides (HoPSs and HePSs) are secreted by a wide variety of Grampositive and Gram-negative bacteria, yeasts, molds, and microalgae (Donot, Fontana, Baccou, \& Schorr-Galindo, 2012). HoPSs produced from sucrose by extracellular glucan- and fructansucrases (Monsan, Bozonnet, \& Albenne, 2001; Zannini, Waters, Coffey, \& Arendt, 2015) contain either Dglucopyranose or D-fructofuranose residues connected by a few glycosidic bond types (Laws, Gu, \& Marshall, 2001), while HePSs are complex and synthesized intracellularly from nucleotide sugars catalyzed by glycosyltransferases yielding oligosaccharide repeats, which are polymerized and secreted as HePS (Schmid, Sieber, \& Rehm, 2015; van Kranenburg, Vos, van Swam, Kleerebezem, \& de Vos, 1999). The repeats contain 3-9 monosaccharide residues, typically glucose (Glc), galactose (Gal), rhamnose (Rha), $N$-acetylglucosamine (GlcNAc), $N$-acetylgalactosamine (GalNAc), or glucuronic acid, in either pyranose or furanose configuration (Broadbent, McMahon, Welker, Oberg, \& Moineau, 2003; De Vuyst, De Vin, Vaningelgem, \& Degeest, 2001). Glycerol, pyruvate (Pyr), phosphate, acetate, and 
other substituents may occur (De Vuyst et al., 2003; Gruter, Leeflang, Kuiper, Kamerling, \& Vliegenthart, 1993, 1992; Nakajima, Hirota, Toba, Itoh, \& Adachi, 1992; Van Calsteren, Gagnon, Nishimura, \& Makino, 2015; Van Calsteren, Pau-Roblot, Bégin, \& Roy, 2002). The molar size of HePSs spans a wide range, and the structural diversity of oligosaccharide repeats is high with regard to monosaccharide composition, anomer configuration, regioselectivity, and substituents.

Exopolysaccharides (EPSs) can protect bacteria against changes in temperature, $\mathrm{pH}$, light intensity, and other environmental stresses (for reviews see (De Vuyst et al., 2001; Donot et al., 2012; Freitas, Alves, \& Reis, 2011; Hidalgo-Cantabrana et al., 2014; Patten \& Laws, 2015)) and are commonly involved in formation and stabilization of biofilms (Sutherland, 2001). Lactic acid bacteria (LAB) produce HePSs in smaller amount than HoPSs (Torino, Font de Valdez, \& Mozzi, 2015), but HePS nevertheless contribute very substantially in improving the physical and rheological properties of fermented milk products (Ayala-Hernández, Hassan, Goff, Mira de Orduña, \& Corredig, 2008; De Vuyst \& Degeest, 1999; Leroy \& De Vuyst, 2004; Mende, Rohm, \& Jaros, 2015). Interaction with milk proteins and water-binding capacity of HePSs have been connected with decreased syneresis, increased viscosity, firmness, creaminess, and a shiny surface of fermented dairy products (Folkenberg, Dejmek, Skriver, \& Ipsen, 2005, 2006). Additionally, HePS-protein interactions may confer beneficial health effects in humans including antitumor activity (Wang et al., 2014), immunomodulation (Chabot et al., 2001; Hidalgo-Cantabrana et al., 2012), antioxidant properties (Zhang et al., 2013), anti-atherosclerotic activity (Tok \& Aslim, 2010), antimutagenicity (Tsuda, Hara, \& Miyamoto, 2008), and biosorption of lead (Feng, Chen, Li, Nurgul, \& Dong, 2012).

Analysis of HoPS-milk protein interactions by surface plasmon resonance (SPR) has previously showed the binding capacity to decrease with $\mathrm{pH}$ increasing from 4.0 to 5.5 and to vary with HoPS linkage type, branching, and molecular size (Babol, Svensson, \& Ipsen, 2011; Diemer et al., 2012). In 
the present work, the SPR methodology was further developed to describe both HePS-protein binding capacity and apparent affinity. In this study, seven structurally diverse LAB HePSs (HePS-1-HePS-7) were used, all previously described in relation to viscosity regulation in yogurt fabrication (Bouzar, Cerning, \& Desmazeaud, 1996; B Degeest, Mozzi, \& De Vuyst, 2002; Doleyres, Schaub, \& Lacroix, 2005; Kimmel, Roberts, \& Ziegler, 1998; Robitaille et al., 2009), immune effect (Bleau et al., 2010; Lebeer, Claes, Verhoeven, Vanderleyden, \& De Keersmaecker, 2011), or prevention of antibioticassociated diarrhea (Vanderhoof et al., 1999). The aim of this study was to test the hypothesis that HePS size and structure determine the ability to bind milk proteins. This procedure can monitor effects of various environmental conditions on polysaccharide-protein interactions in a quantitative manner, disclose functional determinants of HePS-protein complex formation, and screen LAB strains relevant for application in food products as well as the capability to form non-food complexes, e.g. in biofilms.

\section{Materials and methods}

\subsection{HePSs}

HePS-1-HePS-7 were purified from culture supernatants of LAB strains, pre-cultured and fermented (20-48 h) in relevant media (Supplementary Table S1; Supplementary methods S1.1), and subjected to structure analyses (Supplementary methods S1.2 and S1.3). HePSs were quantified using the phenolsulfuric acid method (Dubois, Gilles, Hamilton, Rebers, \& Smith, 1956) with monosaccharide mixtures mimicking oligosaccharide repeat compositions as standards.

\subsection{HePS molar mass $\left(M_{w}\right)$}

Molar mass of HePS-1-HePS-7 was determined by size-exclusion chromatography (SEC) (solvent delivery system (LC-10AD), autosampler (SIL-10A), RI detector (RID-10A); all Shimadzu, Kyoto, 
Japan) on an OH-PK SB-805HQ, $300 \times 8 \mathrm{~mm}$, pore size $500 \AA$ column (Shoko CO., Ltd, Tokyo, Japan) in $10 \mathrm{mM}$ sodium citrate/citric acid pH 4.0. Dextran standards (4.5 MDa, 1.45 MDa, $560 \mathrm{kDa}$, 350 kDa (American Polymer Standards Corporation, Mentor, OH, USA), 276.5 kDa, 196.3 kDa, 123 $\mathrm{kDa}$ (Pharmacosmos, Holbaek, Denmark)) and pullulan of $22 \mathrm{kDa}$ were used for calibration. Standards (1.0-2.7 $\left.\mathrm{mg} \mathrm{ml}^{-1}\right)$ and HePSs $\left(1.0-2.0 \mathrm{mg} \mathrm{ml}^{-1}\right)$ dissolved in the above buffer, degassed, kept overnight, and filtered (0.45 $\mu \mathrm{m}$ filters; Frisenette ApS, Knebel, Denmark) were analyzed (100 $\mu 1)$ at a flow $\begin{array}{llllll} & \text { rate } & \mathrm{ml} & \mathrm{ml} & & \end{array}$ 


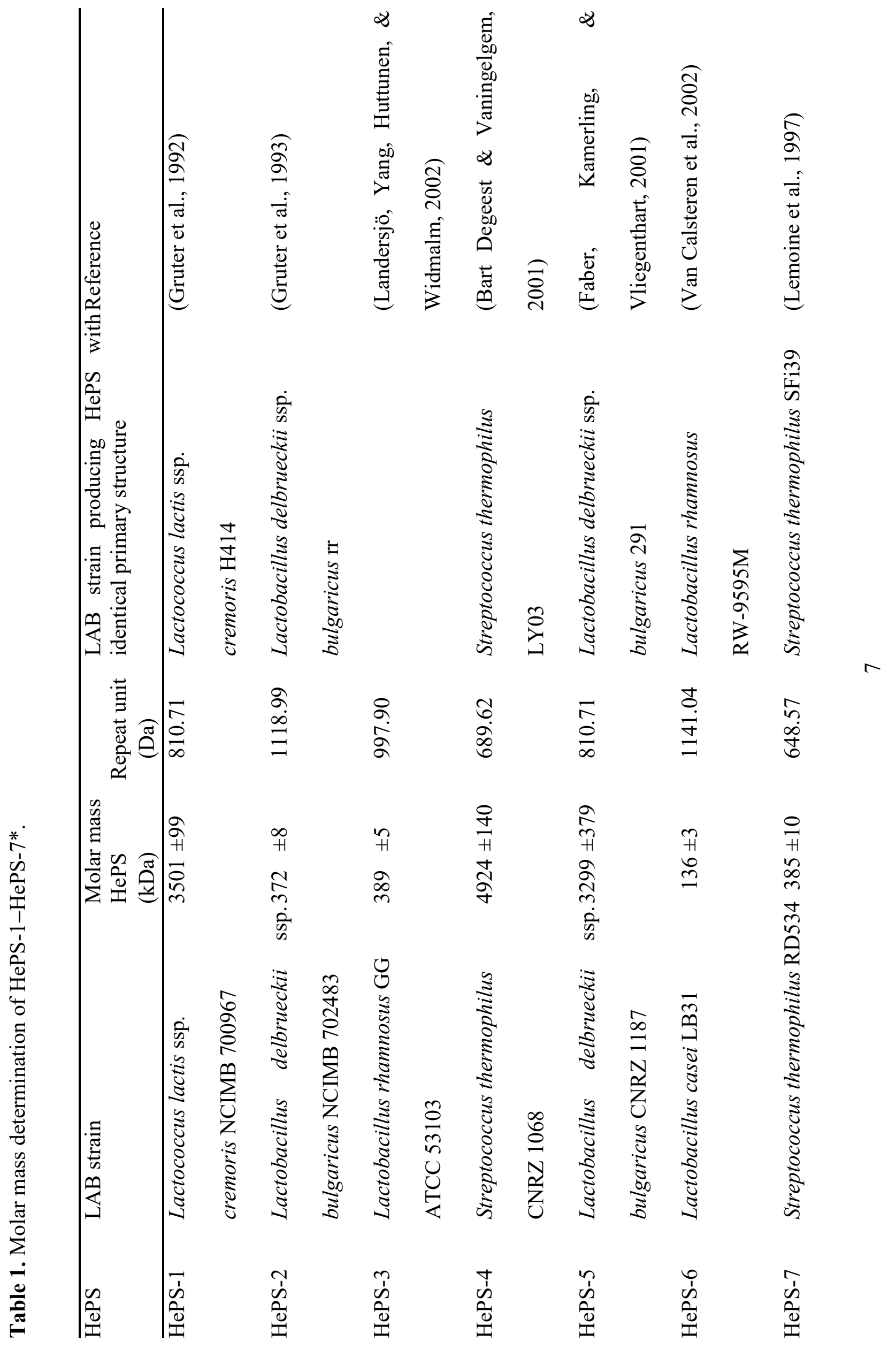




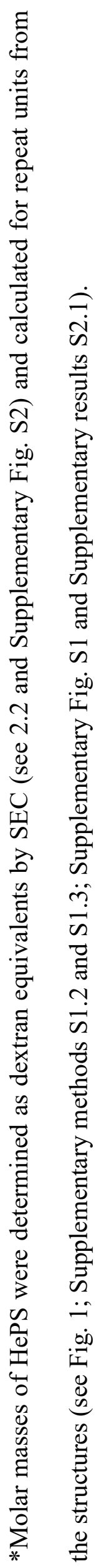


HePS $M$ values were obtained from the standard curve using a linear regression equation:

$$
\log M=9.9387-0.8712 \cdot V_{\mathrm{e}} \quad(\text { eqn. } 1)
$$

where $V_{\mathrm{e}}$ is the elution volume $\left(\mathrm{r}^{2}=0.992\right)$.

\subsection{Milk protein stocks}

Lyophilized $\beta$-lactoglobulin (BLG), $\beta$ - and $\kappa$-caseins (BCN and $\mathrm{KCN}$ ) (all Sigma-Aldrich, St. Louis, MO, USA) were dissolved $\left(1.0 \mathrm{mg} \mathrm{ml}^{-1}\right)$ in $10 \mathrm{mM}$ sodium acetate $\mathrm{pH} 4.0$, centrifuged $\left(20000 \mathrm{~g}, 4^{\circ} \mathrm{C}\right.$, $20 \mathrm{~min}$ ) and the supernatants diluted $\left(50 \mu \mathrm{g} \mathrm{ml}^{-1}\right)$ for sensor chip immobilization (see 2.5.1). BLG (5 $\left.\mathrm{mg} \mathrm{ml}^{-1}\right)$ in $50 \mathrm{mM}$ sodium phosphate $\mathrm{pH} 6.8,30 \mathrm{mM} \mathrm{NaCl}$, was heat-treated $\left(85^{\circ} \mathrm{C}, 15 \mathrm{~min}\right)(\mathrm{hBLG})$ and centrifuged (as above). The supernatant was dialyzed against $10 \mathrm{mM}$ sodium acetate $\mathrm{pH} 4.0$ and diluted $\left(50 \mu \mathrm{g} \mathrm{ml}^{-1}\right)$ for immobilization (see 2.5.1). For dynamic light scattering (DLS) (see 2.4), BLG $\left(5.0 \mathrm{mg} \mathrm{ml} \mathrm{m}^{-1}\right)$ was stirred in deionized water $(150 \mathrm{rpm}, 13 \mathrm{~h}$, room temperature) and centrifuged (as above). Concentrations were determined spectrophotometrically at $280 \mathrm{~nm}$ using molar extinction coefficients $(\varepsilon) 17210,11460$, and $19035 \mathrm{M}^{-1} \mathrm{~cm}^{-1}$ calculated by ProtParam (Gasteiger et al., 2005) from amino acid sequences for $\mathrm{BLG}, \mathrm{BCN}$, and $\mathrm{KCN}$, respectively (GenBank accessions: BLG, 2Q2M_A; BCN, AAA30431; KCN, CAA33034).

\subsection{Dynamic light scattering}

Lyophilized HePS-3 in deionized water $\left(3 \mathrm{mg} \mathrm{ml}^{-1}\right)$ was left overnight at $4^{\circ} \mathrm{C}$ for complete dissolution, filtered $(0.45 \mu \mathrm{m}$ filters; Frisenette ApS), mixed with BLG (see 2.3) to final 0.1 and $1.0 \mathrm{mg}$ $\mathrm{ml}^{-1}$, respectively, in $10 \mathrm{mM}$ sodium citrate $(\mathrm{pH} \mathrm{3-6)}$ or Tris- $\mathrm{HCl}(\mathrm{pH} \mathrm{7-8)}$ and equilibrated 30 min prior to DLS analysis. Particle sizes of HePS-3, BLG, and HePS-3+BLG mixtures were analyzed $\left(23^{\circ} \mathrm{C}\right.$, scattering angle $90^{\circ}$; BI-200SM; Brookhaven Instruments Corporation, Holtsville, NY, USA) 
and the distributions of mean apparent translational diffusion coefficients $\left(D_{\mathrm{T}}\right)$ determined by fitting the DLS autocorrelation functions (obtained with the Brookhaven system) using nonnegative constrained least squares. Distribution of mean apparent $D_{\mathrm{T}}$ was converted to distribution of hydrodynamic diameter $\left(d_{\mathrm{H}}\right)$ using the Stokes-Einstein equation:

$$
d_{\mathrm{H}}=k T / 3 \pi \eta D_{\mathrm{T}} \quad(\text { eqn. } 2)
$$

where $k$ is the Boltzmann constant $\left(1.38 \cdot 10^{-23} \mathrm{~J} / \mathrm{K}\right), T$ the absolute temperature, and $\eta$ the solvent viscosity $(0.93 \mathrm{mPa} \cdot \mathrm{s}$; assumed to be that of water at $296 \mathrm{~K})$.

\subsection{Surface plasmon resonance}

\subsubsection{Protein immobilization}

Proteins (see 2.3) were covalently coupled to SPR sensor chips (CM5, CM4, C1; GE Healthcare, Uppsala, Sweden) using the automatic immobilization wizard (Biacore T100 Control Software; GE Healthcare) at $10 \mu \mathrm{min}^{-1}$ and Amine Coupling Kit (GE Healthcare) for sample flow cell, while the reference flow cell underwent the same treatment without protein. CM4 and CM5 were prepared by 7 min injections of i) $0.05 \quad \mathrm{M} \quad N$-hydroxysuccinimide, $\quad 0.2 \quad \mathrm{M} \quad$ 1-ethyl-3-(3dimethylaminopropyl)carbodiimide, ii) protein $\left(50 \mu \mathrm{g} \mathrm{ml}^{-1}\right.$ in $10 \mathrm{mM}$ sodium acetate $\left.\mathrm{pH} 4.0\right)$, and iii) 1 $\mathrm{M}$ ethanolamine $\mathrm{pH} 8.5$ to block remaining activated carboxyl groups. $\mathrm{C} 1$ was washed $2 \times 1$ min with $0.1 \mathrm{M}$ glycine- $\mathrm{NaOH} \mathrm{pH}$ 12.0, 0.3\% (v/v) Triton X-100 followed by activation, immobilization, and blocking of activated carboxyl groups as above.

\subsubsection{SPR analysis}

Standard SPR analysis $\left(25^{\circ} \mathrm{C}\right.$; Biacore T100; GE Healthcare) in running buffer of ionic strength similar to milk (10 mM sodium acetate $\mathrm{pH} 4.0,70 \mathrm{mM} \mathrm{NaCl}, 0.005 \%$ surfactant P20; GE Healthcare) 
(Babol et al., 2011) comprised $180 \mathrm{~s}$ association, $60 \mathrm{~s}$ dissociation, two consecutive 60 and $30 \mathrm{~s}$ regeneration cycles (10 mM 4-(2-hydroxyethyl)-1-piperazineethanesulfonic acid pH 9.0, $1 \mathrm{M} \mathrm{NaCl,} 3$ $\mathrm{mM}$ ethylenediaminetetraacetic acid, $0.005 \%$ surfactant $\mathrm{P} 20$ ) and $300 \mathrm{~s}$ equilibration (running buffer). Influence of $\mathrm{pH}(4.0-5.0)$ and $\mathrm{NaCl}(70-200 \mathrm{mM})$ was assessed. Temperature $\left(25-35^{\circ} \mathrm{C}\right)$ effect was analyzed under standard conditions. Binding of HePS-1-HePS-7 was analyzed at seven concentrations (1-200 $\mu \mathrm{g} \mathrm{ml}^{-1}$ ) using $60 \mu \mathrm{min}^{-1}$ to minimize mass transport effects. The change in refractive index caused by the accumulation of HePS interacting with the immobilized protein on the sensor surface is reported in response units (RU), where the sensorgram is in measured RU plotted versus time. After each HePS series, two samples below the critical HePS concentration (see 3.2.1) were analyzed to evaluate reproducibility. HePS-1 (10 $\left.\mu \mathrm{g} \mathrm{ml} \mathrm{ml}^{-1}\right)$, showing robust and reproducible well-fitted sensorgrams, was used as a control to monitor the protein surface activity before and after each HePS interaction series. Reference cell and buffer blank responses were subtracted from sensorgrams to correct for nonspecific binding to the surface, mechanical drift, and external systemic noise (Myszka, 2000). Data were processed using Scrubber2 (Biologic Software Pty. Ltd., Campbell, Australia) and an in-house script (in MATLAB; The MathWorks, Natick, MA, USA) calculating steady-state response values at equilibrium $\left(\mathrm{RU}_{\mathrm{eq}}\right)$ by averaging the signal at $6-4 \mathrm{~s}$ prior to dissociation. Steadystate analyses adopted a 1:1 Langmuir interaction model (Myszka, 2000):

$$
\mathrm{RU}_{\max }=\mathrm{RU}_{\mathrm{eq}} \cdot C /\left(C+K_{\mathrm{D}, \mathrm{app}}\right) \quad(\text { eqn. } 3)
$$

$\mathrm{RU}_{\text {eq }}$ is the steady-state response at HePS concentration $C$ and $K_{\mathrm{D} \text {,app }}$ the apparent equilibrium dissociation constant. $\mathrm{RU}_{\max }$ is the maximum HePS binding capacity of the protein surface. $K_{\mathrm{D} \text {,app }}$ and $\mathrm{RU}_{\max }$ were calculated by plotting $\mathrm{RU}_{\mathrm{eq}}$ against $C$ and using nonlinear least-squares fitting routines 


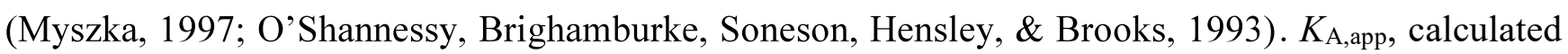
as $1 / K_{\mathrm{D} \text {,app }}$, is the apparent equilibrium association constant.

\section{Results and Discussion}

\subsection{HePS structure and size}

HePS-1-HePS-7 oligosaccharide repeat structures (Fig. 1) were confirmed by ${ }^{1} \mathrm{H}$ nuclear magnetic resonance spectra (Supplementary Fig. S1) judged to be identical to spectra of HePSs from authentic strains or in the literature (Table 1). Sugar compositions were verified for the rhamnose-containing HePS-2, HePS-3, and HePS-6 (Supplementary results S2.1), and the HePS-7 oligosaccharide repeat was prepared and characterized by mass spectrometry (Supplementary results $\mathrm{S} 2.1$ ). $M_{\mathrm{w}}$ contributes to function (Cerning, Bouillanne, Landon, \& Desmazeaud, 1992; De Vuyst \& Degeest, 1999; van den Berg et al., 1995) and was determined by SEC (Table 1; Supplementary Fig. S2). 
HePS-1

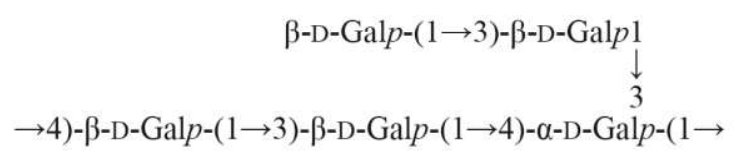

HePS-2

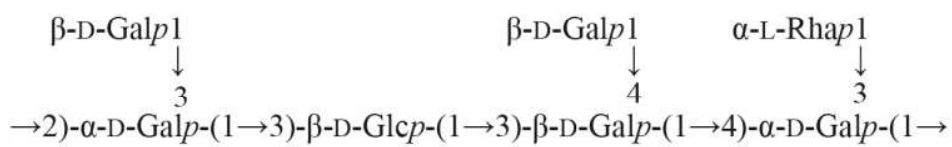

HePS-3

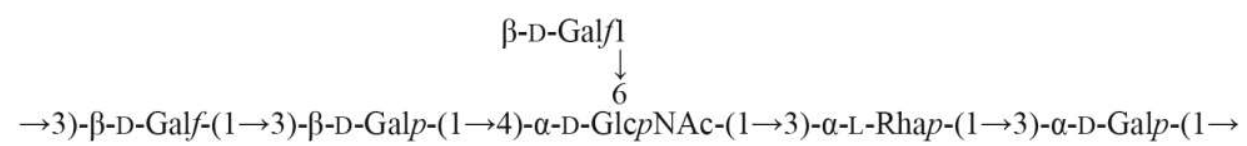

HePS-4

$$
\begin{gathered}
\alpha-\mathrm{D}-\mathrm{Gal} p \\
\downarrow \\
\downarrow \\
6 \\
\rightarrow 3)-\beta-\mathrm{D}-\mathrm{Gal} p-(1 \rightarrow 3)-\beta-\mathrm{D}-\mathrm{Glc} p-(1 \rightarrow 3)-\alpha-\mathrm{D}-\mathrm{Gal} p \mathrm{NAc}-(1 \rightarrow
\end{gathered}
$$

\section{HePS-5}

$$
\begin{aligned}
& \beta \text {-D-Galp-(1-4)- } \beta \text {-D-Glc } p 1 \\
& \begin{array}{l}
\downarrow \\
6
\end{array} \\
& \rightarrow 4)-\beta \text {-D-Glc } p-(1 \rightarrow 4)-\alpha-\mathrm{D}-\mathrm{Glc} p-(1 \rightarrow 4)-\beta-\mathrm{D}-\mathrm{Gal} p-(1 \rightarrow
\end{aligned}
$$

HePS-6

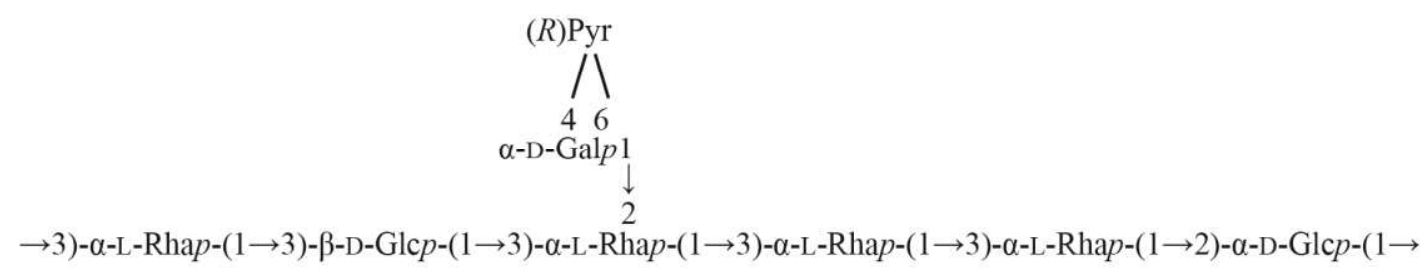

HePS-7

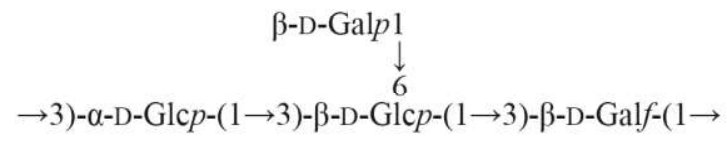

Figure 1 Structures of HePS repeat units. HePS-1 (Lactococcus lactis ssp. cremoris NCIMB 700967), HePS-2 (Lactobacillus delbrueckii ssp. bulgaricus NCIMB 702483), HePS-3 (Lactobacillus rhamnosus GG (ATCC 53103)), HePS-4 (Streptococcus thermophilus CNRZ 1068), HePS-5 (Lactobacillus delbrueckii ssp. bulgaricus CNRZ 1187), HePS-6 (Lactobacillus casei LB31), and HePS-7 (Streptococcus thermophilus RD534). 


\subsection{SPR analysis of HePS-milk protein interaction}

\subsubsection{SPR protocol development}

SPR analyses were previously used to determine binding between HoPS $\left(0.5 \mathrm{mg} \mathrm{ml}^{-1}\right)$ and milk proteins immobilized at high density $(\mathrm{RU}=1130-4200)$ on a dextran-coated CM4 sensor chip (Babol et al., 2011; Diemer et al., 2012). Surprisingly, HePS-3 (0.5 mg ml$\left.{ }^{-1}\right)$ exhibited more pronounced binding to the CM5 and CM4 reference cell compared to the native BLG (nBLG) sample cell, even at lower protein density $(\mathrm{RU}=395)$ than used in the HoPS study (Fig. 2A-B). Similar reference cell binding to CM5 and CM4 was observed for all HePSs analyzed in this study (data not shown).

A

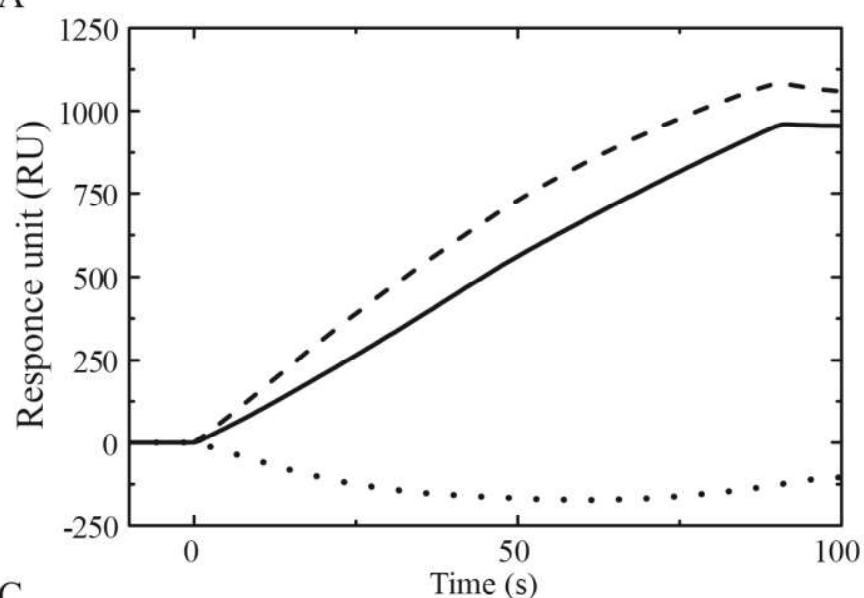

C

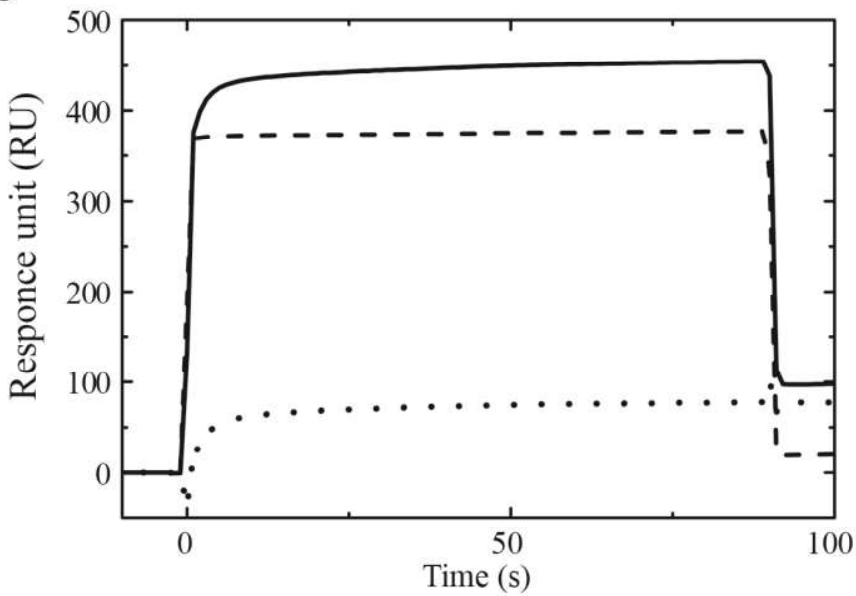

B

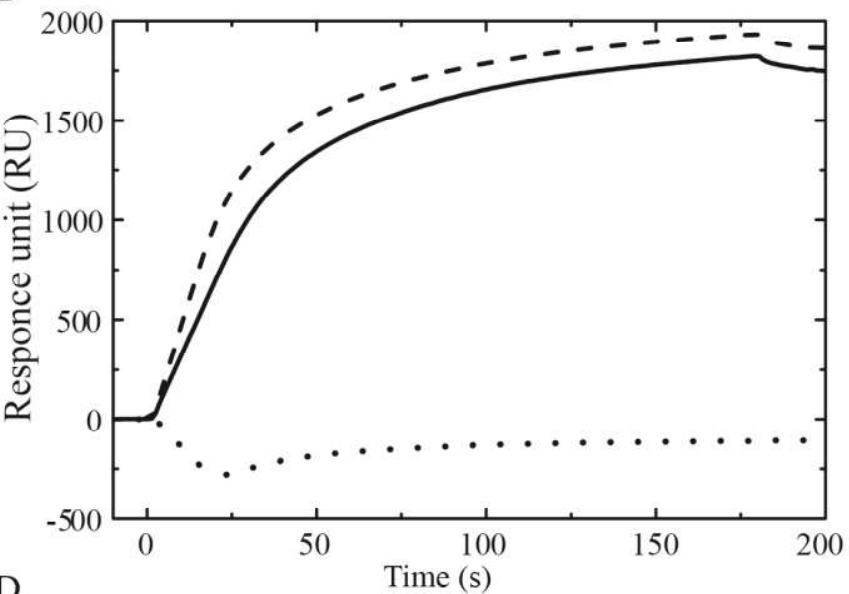

$\mathrm{D}$

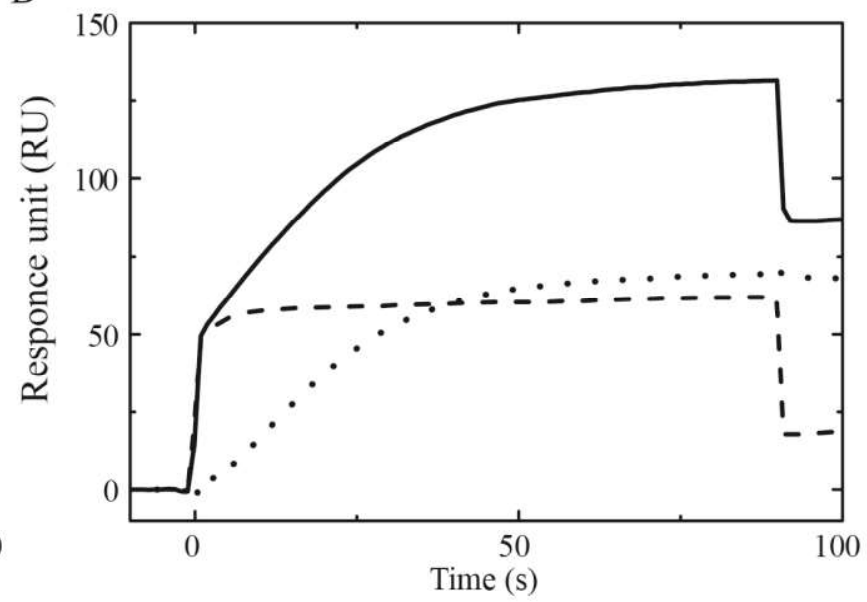

Figure 2 Sensorgrams of HePS-3 and native $\beta$-lactoglobulin (nBLG) immobilized on different SPR sensor chips. Reference cell: dashed line; sample cell: solid line; difference sensorgram: dotted line. A) HePS-3 (0.5 mg ml-1) 
injected on CM5 with 395 RU immobilized nBLG; B) HePS-3 $\left(0.5 \mathrm{mg} \mathrm{m}^{-1}\right)$ injected on a CM4 sensor chip with 190 RU immobilized nBLG. C) $0.4 \mathrm{mg} \mathrm{ml}^{-1} \mathrm{HePS}-3$ injected on a C1 chip with $75 \mathrm{RU}$ immobilized nBLG. D) $0.04 \mathrm{mg} \mathrm{ml}^{-1} \mathrm{HePS}-3$ injected on a $\mathrm{C} 1 \mathrm{chip}$ with $75 \mathrm{RU}$ immobilized nBLG.

Both the CM5 and the CM4 sensor chips are dextran coated, with the CM4 chip having a shorter dextran layer and a lower carboxyl group density than the CM5 chip. Considering sample and reference cell responses as signal and noise, respectively, the signal-to-noise ratio (SNR) was 0.88 with nBLG CM5 and improved only 5\% when using nBLG CM4. Remarkably, adverse HePS-dextran binding was avoided using the matrix-free $\mathrm{C} 1$ chip that raised the SNR by $36 \%$ at $0.4 \mathrm{mg} \mathrm{ml}^{-1}$ and $150 \%$ at $0.04 \mathrm{mg}$ $\mathrm{ml}^{-1}$ HePS-3 (Fig. 2C-D) compared to CM5. The sensorgram shape clearly indicated rapid saturation of the $\mathrm{C} 1$ reference cell by HePS-3 and the binding to $\mathrm{nBLG} \mathrm{C} 1$ approached steady state at the end of injection (Fig. 2D). Additionally, the density of immobilized protein was kept low minimizing the two common SPR obstacles; mass transport limitations; and crowding (Myszka \& Morton, 1998). Slow dissociation, however, as also previously found in SPR analysis of $\alpha$-glucan HoPS-milk protein and a lacquer polysaccharide-polylysine binding (Bai \& Yoshida, 2013; Diemer et al., 2012) made C1 chip regeneration necessary for all HePSs, and the effectiveness of this was confirmed by superb reproducibility for binding (in duplicate) of 1 and $6 \mu \mathrm{g} \mathrm{ml} \mathrm{m}^{-1} \mathrm{HePS}-3$ (Fig. 3A). Importantly, at high concentrations of injected HePS, binding to the $\mathrm{C} 1$ reference cell was arising causing a decrease in the $\mathrm{RU}_{\text {eq }}$ upon steady-state binding analysis (Supplementary Fig. S3). The acceptable HePS concentration entailing minuscule binding to the reference cell was HePS specific and referred to as the critical HePS concentration. Below the critical HePS concentrations ranges, the assay reliably featured typical sensorgrams allowing determination of maximum binding capacity $\left(\mathrm{RU}_{\max }\right)$ and $K_{\mathrm{D} \text {,app }}$ (Fig. $\left.3 \mathrm{~A}-\mathrm{B}\right)$, which represents a major advancement over the previous established SPR procedure (Babol et al., 2011; Diemer et al., 2012). The steady-state binding curve analysis (Fig. 3B) indicated apparent affinity 
for protein and HePS - most likely undergoing multiple binding, hence the slow dissociation (Myszka, 2000). Avidity effects are inherent to the polysaccharide structure and have physiological relevance in biofilms (Sheppard \& Howell, 2016) as well as importance for industrial associative polysaccharide-milk protein interactions involved in texturizing microstructures of dairy products (Folkenberg et al., 2006).

For statistical evaluation of the SPR procedure, assays with nBLG immobilized at three different levels were carried out (Table 2). Although the immobilization level increased by $\sim 300 \%$ from 288 to 866 $\mathrm{RU}$, the apparent affinity was only little affected yielding an average $K_{\mathrm{A} \text {,app }}$ of $0.208 \pm 0.022 \mathrm{nM}$.

Table 2. Binding of HePS-3 to native $\beta$-lactoglobulin at three different immobilization levels (RU) on a $\mathrm{C} 1$ chip.

\begin{tabular}{lll}
\hline $\begin{array}{l}\text { Immobilization level } \\
(\mathrm{RU})\end{array}$ & $\begin{array}{l}K_{\mathrm{A}, \mathrm{app}} \\
(\mathrm{nM})\end{array}$ & $\begin{array}{l}\text { Average } K_{\mathrm{A}, \mathrm{app}} \\
(\mathrm{nM})\end{array}$ \\
\hline 288 & 0.217 & \\
311 & 0.230 & $0.208 \pm 0.022$ \\
866 & 0.178 & \\
\hline
\end{tabular}

Additionally, two negative control polysaccharides, showing only minuscule binding to the referencecell and no binding to the sample-cell with immobilized BLG, support the protein binding by HePS (Supplementary Fig. S4). 

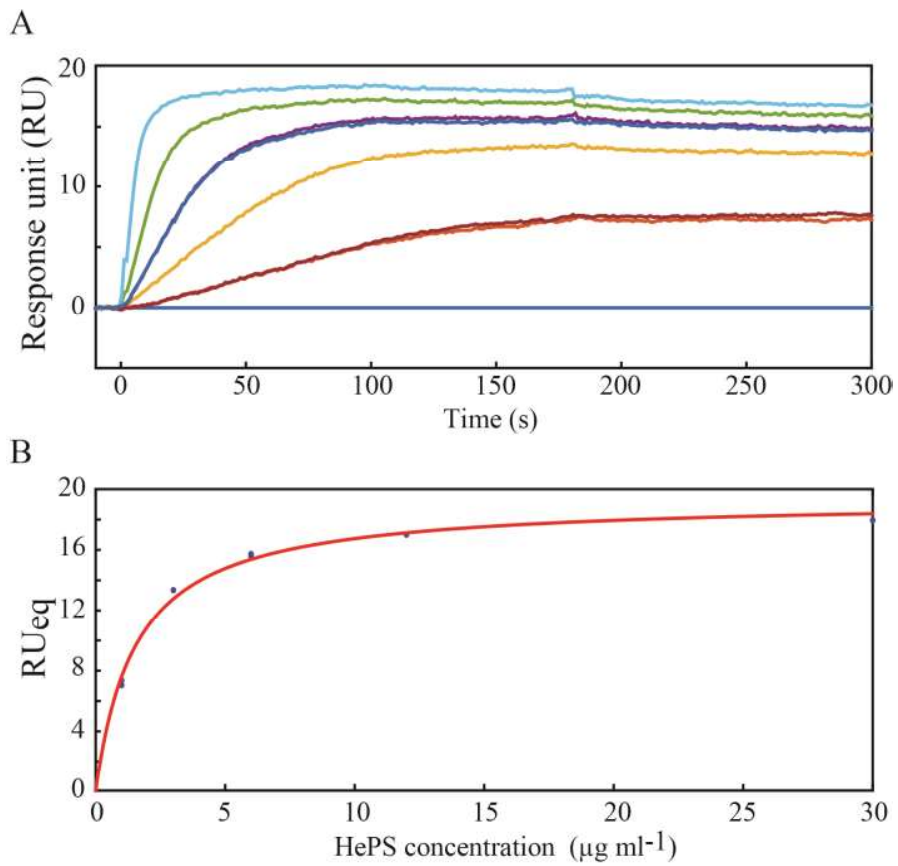

Figure 3 SPR binding curves between HePS-3 and immobilized native $\beta$-lactoglobulin (nBLG) on a C1 chip $(\mathrm{RU}=288)$. A) SPR sensorgrams of HePS-3 injected for $180 \mathrm{~s}$ followed by $120 \mathrm{~s}$ dissociation. HePS was injected with the following concentrations $\left(\mu \mathrm{g} \mathrm{ml}^{-1}\right)$ : 0 , blue; 1 in duplicate, red and bordeaux; 3, yellow; 6 in duplicate, purple and dark blue; 12, green; 30, light blue. B) Steady-state analysis determination of $\mathrm{RU}_{\max }$ and $K_{\text {Dapp }}$ using fitting to a 1:1 binding model.

\subsubsection{HePS-3 interaction with native $\beta$-lactoglobulin}

A pH increase from 4.0 to 4.5 caused $K_{\mathrm{A} \text {,app }}$ and $\mathrm{RU}_{\max }$ for HePS-3 and nBLG to decrease 1.3- and 2.9fold, respectively (Table 3), while no binding was observed at $\mathrm{pH} 5.0$ near the reported nBLG pI of 4.7-5.3 (Mercadante et al., 2012; Sakurai, Konuma, Yagi, \& Goto, 2009; Verheul, 1998). Reduced net charge of nBLG or change in ionization state of one or more critical side chains may suppress binding at $\mathrm{pH}$ 5.0. At pH 4.0 and $100 \mathrm{mM} \mathrm{NaCl}, K_{\mathrm{A} \text {,app }}$ and $\mathrm{RU}_{\max }$ decreased 2.3- and 1.4-fold compared to 70 $\mathrm{mM} \mathrm{NaCl}$ (Table 3); no interaction was detected at $200 \mathrm{mM} \mathrm{NaCl}$. 
Table 3. Binding of HePS-3 to native $\beta$-lactoglobulin on $\mathrm{C} 1$ chip.

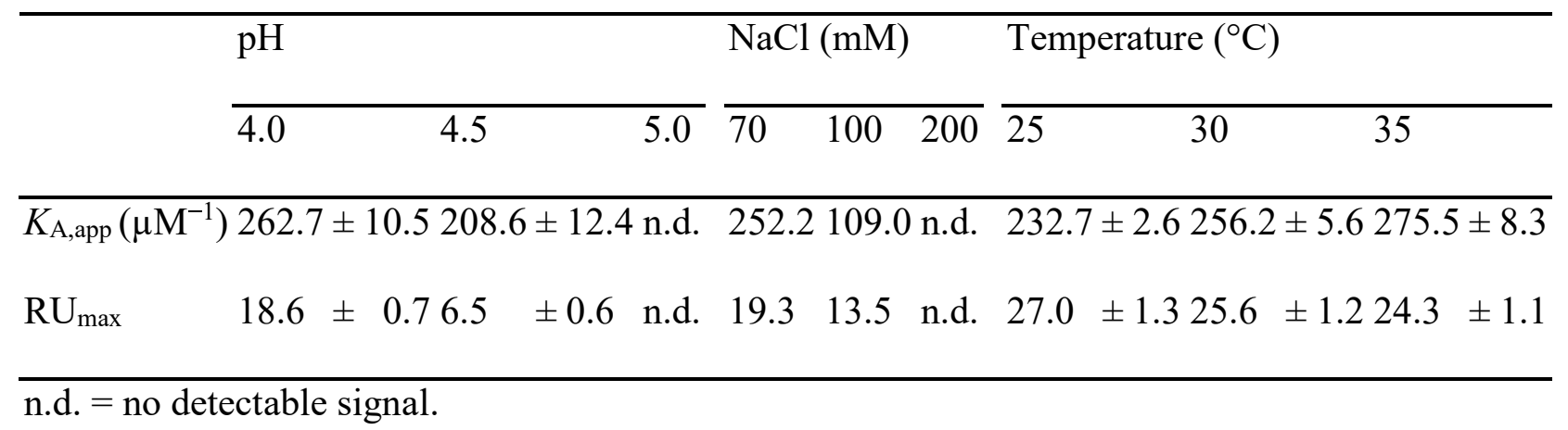

The effects of $\mathrm{pH}$ and ionic strength suggest that polar interactions are important for complexation, while the modest increase in $K_{\mathrm{A} \text {,app }}$ with increasing temperature $\left(25-35^{\circ} \mathrm{C}\right)$ (Table 3$)$ indicated minimal role of hydrophobic interactions.

DLS analysis (Fig. 4) supported the pH dependence of HePS-3 binding. $d_{\mathrm{H}}$ of nBLG was constant at $6.0 \pm 0.4 \mathrm{~nm}$ in $70 \mathrm{mM} \mathrm{NaCl}$ at $\mathrm{pH} \mathrm{3-8,} \mathrm{thus} \mathrm{close} \mathrm{to} 7 \mathrm{~nm}$ reported for the BLG dimer (Baldini et al., 1999). HePS-3 had $d_{\mathrm{H}}-$ in the range $100.9 \pm 2.7-106.0 \pm 3.1 \mathrm{~nm}$ at $\mathrm{pH} 3-6$ (Fig. 4, insert). In the absence of salt, BLG and HePS-3 gave $d_{\mathrm{H}}$ values of $8.2 \pm 0.2 \mathrm{~nm}$ and $118.3 \pm 0.7 \mathrm{~nm}$, respectively, thus no remarkable size difference appeared as a consequence of the presence of $\mathrm{NaCl}$ for the two free molecules (data not shown). HePS-3-nBLG mixture had a stable particle mean $d_{\mathrm{H}}=37.6 \pm 2.9 \mathrm{~nm}$ at $\mathrm{pH}$ $>5$ increasing to a maximum mean $d_{\mathrm{H}}$ at $\mathrm{pH} 4$ of $184.6 \pm 1.3 \mathrm{~nm}$. In absence of $\mathrm{NaCl}, d_{\mathrm{H}}$ of HePS-3nBLG increased to $448.0 \pm 4.8 \mathrm{~nm}$, thus electrostatic shielding weakened HePS-3-nBLG interactions, in accordance with $\mathrm{pH}$ and ionic strength effects shown also by SPR. Similarly, DLS data collected at $173^{\circ}$ for the HePS-3-BLG mixture in $10 \mathrm{mM}$ sodium citrate $\mathrm{pH} 4.0$ gave $d_{\mathrm{H}}$ values of $246 \pm 11 \mathrm{~nm}$ and $50 \pm 3 \mathrm{~nm}$ in the absence and presence of salt, respectively. 


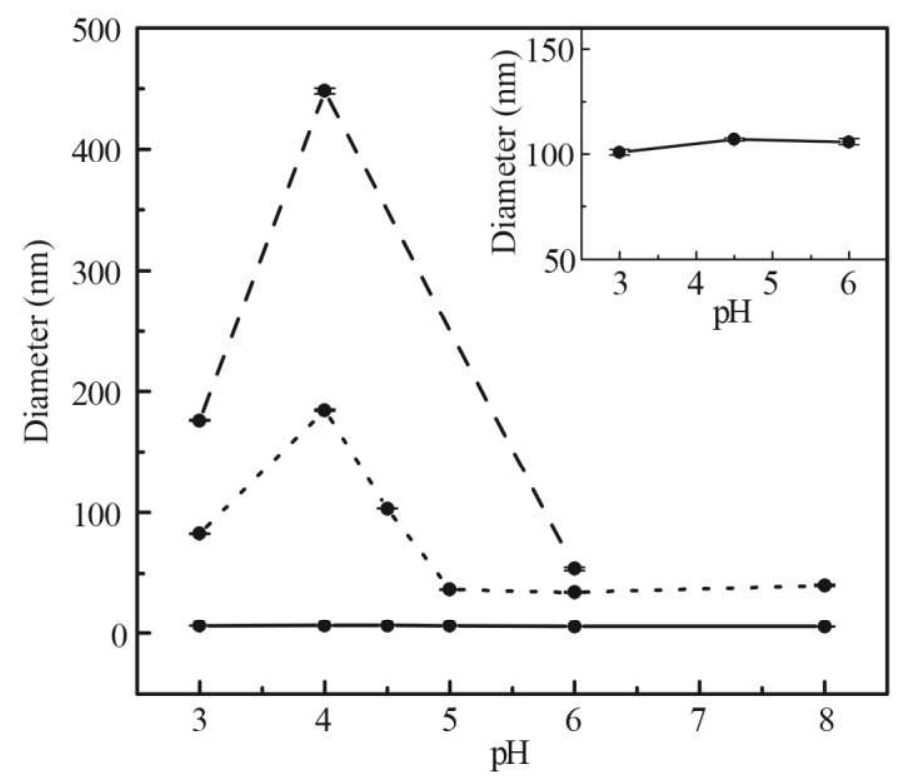

Figure 4 DLS of HePS-3 interacting with native $\beta$-lactoglobulin (nBLG) at different $\mathrm{pH}$. Solid line: $1 \mathrm{mg} \mathrm{m}^{-1}$ $\mathrm{nBLG}$ in $70 \mathrm{mM} \mathrm{NaCl}$. Dotted line: $1 \mathrm{mg} \mathrm{ml}^{-1} \mathrm{nBLG}$ mixed with $0.1 \mathrm{mg} \mathrm{ml}^{-1} \mathrm{HePS}-3$ in $70 \mathrm{mM} \mathrm{NaCl}$. Dashed line: $1 \mathrm{mg} \mathrm{ml}^{-1} \mathrm{nBLG}$ mixed with $0.1 \mathrm{mg} \mathrm{ml}^{-1} \mathrm{HePS}-3$ without $\mathrm{NaCl}$. Insert: Size of HePS-3 as function of $\mathrm{pH}$ in $70 \mathrm{mM} \mathrm{NaCl}$.

\subsubsection{HePS binding capacity}

Noise level and activity of the $\mathrm{C} 1$ protein surface were assessed as stable during the entire assay (Supplementary results S2.2).Every HePS bound well to nBLG, BCN, KCN, and hBLG (Fig. 5; Supplementary Table S2), with few exceptions. Thus no interaction was observed between nBLG and any of the HePSs at $\mathrm{pH} 5.0$, and for HePS-2 also at $\mathrm{pH} 4.5$ (Fig 5A). No interaction was detected between HePS-6 with any of the four proteins at $\mathrm{pH}$ 5.0. Moreover, protein surface saturation was not achieved below the HePS critical concentration level for nBLG-HePS-2 (pH 4.0), BCN-HePS-7 (pH 4.5), KCN-HePS-2 (pH 5.0), hBLG-HePS-5 (4.5), and hBLG-HePS-7 (pH 4.0) (Fig. 5A).

Generally, $\mathrm{RU}_{\max }$ decreased when $\mathrm{pH}$ increased from 4.0 to 5.0 (Fig. 5A; Supplementary Table S2), resembling SPR data of $\alpha$-glucan HoPSs binding milk proteins (Babol et al., 2011; Diemer et al., 2012). pI for $\mathrm{nBLG}$ was about 5 and calculated to 5.37 for BCN and 6.29 for $\mathrm{KCN}$ (Gasteiger et al., 2005) and 
$\mathrm{RU}_{\max }$ decrease from $\mathrm{pH} 4.0$ to 5.0 may stem from reduced protein net charge. Remarkably, average $\mathrm{RU}_{\max }$ at $\mathrm{pH} 4.0$ of all HePSs to $\mathrm{BCN}$ (406 RU) was roughly $40 \%$ of $\mathrm{RU}_{\max }$ obtained with $\mathrm{KCN}$ (406 RU), while nBLG (512 RU) only reached around 15\% of average $\mathrm{RU}_{\max }$ with $\mathrm{KCN}$. The same ranking for the proteins were found with $\alpha$-glucan HoPS where $\mathrm{RU}_{\max }$ at $\mathrm{pH} 4.0$ was about $50 \%$ with $\mathrm{BCN}$ and $15 \%$ with nBLG of the $\mathrm{RU}_{\max }$ value for $\mathrm{KCN}$ (Babol et al., 2011). Notably, $\mathrm{RU}_{\max }$ was $>10$-fold higher with hBLG (1023 RU) than nBLG (512 RU). This, together with binding occurring at pH 5.0 to hBLG but not to nBLG, underscores that heat-treated BLG has increased HePS binding capacity. This may be explained from previous structural analysis establishing that heat treatment of BLG $\left(>80^{\circ} \mathrm{C}\right)$ triggers an incipient unfolding of BLG leading to increased exposure of inner hydrophobic amino acid side chains (Moro, Báez, Busti, Ballerini, \& Delorenzi, 2011). Finally, to preclude that lack of detected BLGHePS binding at pH 5.0 was not due to low immobilization level of nBLG (512 RU), a C1 surface with nBLG immobilized at equivalent level (1022 RU) as the hBLG surface (1023 RU) was established and proven unable to bind any of the analyzed HePSs at pH 5.0 (data not shown). 

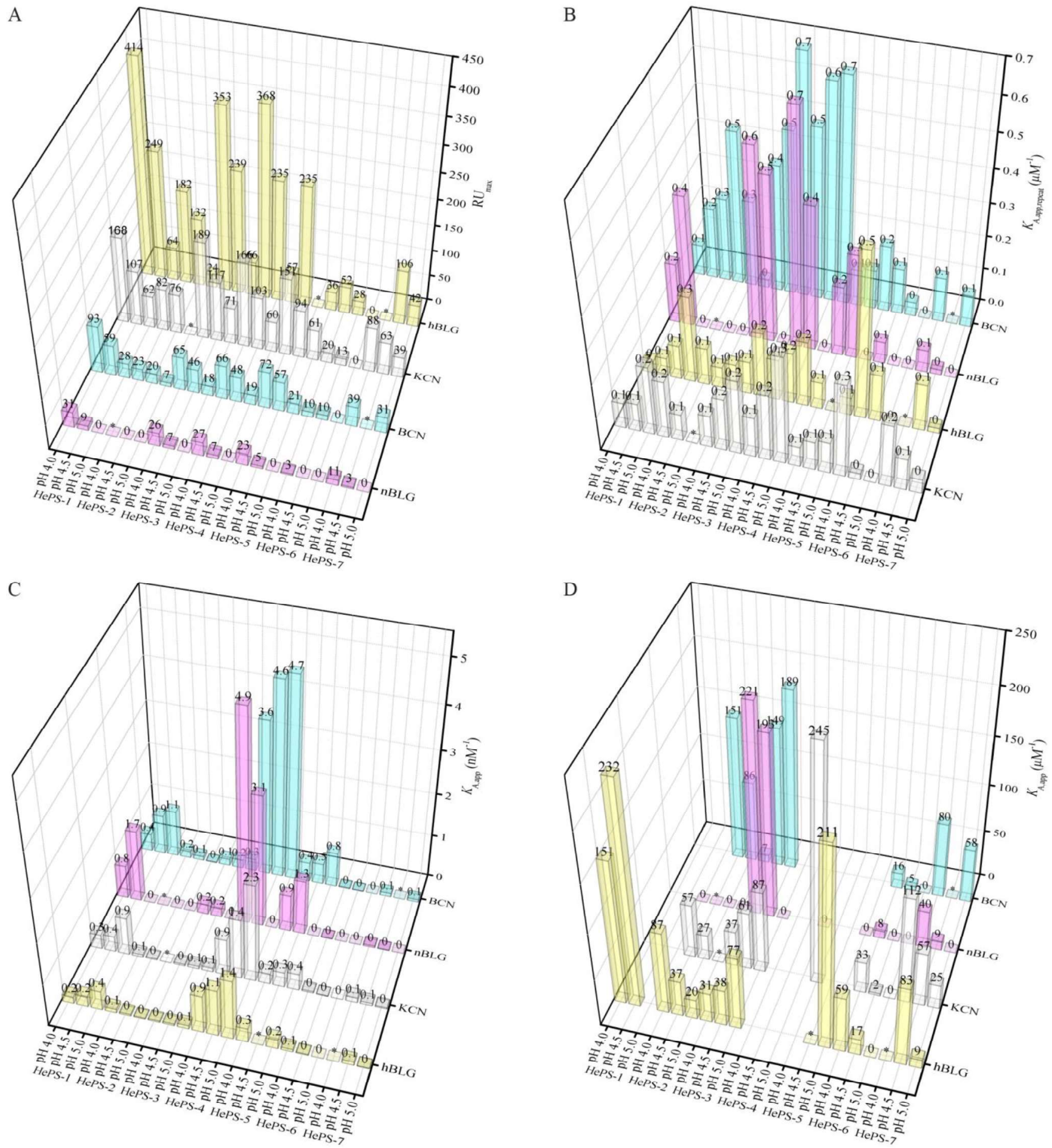

Figure 5 Binding parameters ( $\mathrm{RU}_{\max }, K_{\mathrm{D} \text {,app}}$, and $\left.K_{\mathrm{D} \text {,app,repeat }}\right)$ for HePS-1-HePS-7 with native $\beta$-lactoglobulin (nBLG, magenta), $\beta$-casein (BCN, cyan), $\kappa$-casein $(\mathrm{KCN}$, white), and heat-treated $\beta$-lactoglobulin (hBLG, yellow) as a function of $\mathrm{pH}$ in the range 4.0-5.0. A) $\mathrm{RU}_{\max }$, B) molar affinities by moles of repeating units, $\left.K_{\mathrm{A} \text {,app,repeat }}\left(\mu \mathrm{M}^{-1}\right), \mathrm{C}\right)$ molar affinities by moles of HePS, $K_{\mathrm{A} \text {,app }}\left(\mathrm{nM}^{-1}\right) . K_{\mathrm{A} \text {,app }}$ below $2.5 \mathrm{nM}^{-1}$ are illustrated in 
figure $\mathrm{D}$ in $\mu \mathrm{M}^{-1}$ for better inspection of the low values. Asterisks represent cases where steady state was not achievable. As the ranges spanned are rather large, and the numbers represented are rounded off the raw data are reported in Supplementary Table S2.

HePS-2, HePS-6, and HePS-7 gave low (HePS-6 the lowest) RUmax values with all four proteins and no binding at $\mathrm{pH}$ 5.0. Low $\mathrm{RU}_{\max }$ values may be explained by the relatively small size of these HePSs (Table 1). HePS-3, however, had similar molar mass as HePS-2 and HePS-7, but gave very high $\mathrm{RU}_{\max }$, indicating HePS binding capacity and, most probably, binding affinity are influenced by other properties than the molar mass (see 3.2.4).

\subsubsection{Affinity of milk proteins for HePSs}

The molar $K_{\mathrm{A} \text {,app }}$ for all four investigated protein surfaces varied $>3$-fold in the $\mathrm{pH}$ range $4.0-5.0$ for HePS-2, HePS-6, and HePS-7 (except for HePS-7-BCN and HePS-2-KCN), but from negligibly to 3fold for HePS-1 and HePS-3-HePS-5 (Fig. 5C-D; Supplementary Table S2). By contrast, the $K_{\mathrm{A} \text {,app }}$ for HePS-7-BCN and HePS-2-KCN was only modestly affected ( 1.4- and $\sim 2.1$-fold) in the pH range 4.0-5.0. The largest affinity reduction was observed for HePS-2-BCN (>20-fold) from $\mathrm{pH} 4.0$ to 5.0

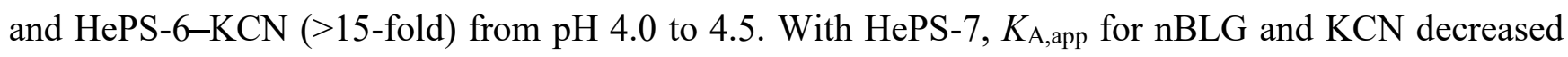

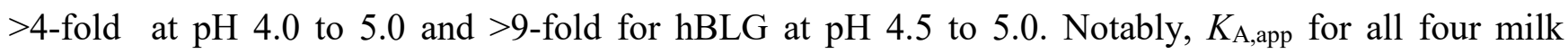
proteins, except for the HePS-2-nBLG complex, was reduced as $\mathrm{pH}$ increased to $\mathrm{pH}$ 5.0. By contrast, although changes in $K_{\mathrm{A} \text {,app }}$ for HePS-1 and HePS-3-HePS-5 were modest ( $<3$-fold), their affinity had a tendency to increase with increasing $\mathrm{pH}$ in the range 4.0-5.0, except for HeSP-3-nBLG, HePS-4nBLG and HePS-5-hBLG displaying a small affinity decrease of $\sim 1.1-, \sim 1.6-$ and $\sim 1.6$-fold, respectively. 
Highest apparent affinity of all four protein surfaces was observed with nBLG and BCN binding HePS-1, HePS-4, HePS-5, and to some degree with HePS-3 (Fig. 5C-D; Supplementary Table S2). A large molar mass of HePS-1, HePS-4, and HePS-5 (3.3-4.9 MDa; Table 1) compared to HePS-2,

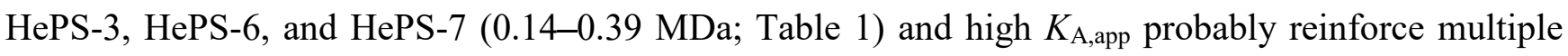
binding and avidity effects (Fig. 5C-D; Supplementary Table S2). Still, HePS-2, HePS-3, and HePS-7, despite similar molar mass of around 0.3 $\mathrm{MDa}$, bound milk proteins with different affinity and $\mathrm{pH}$ dependency, indicating that other properties of HePSs than molar mass contribute to the protein affinity.

Molar affinity $\left(K_{\mathrm{A} \text {,app,repeat }}\right)$ based on repeat unit size (648.57-1141.04 Da; Table 1) ignores the large

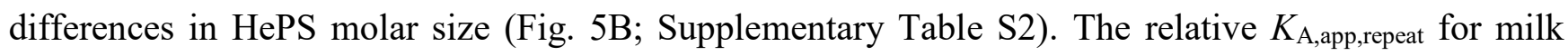
proteins was generally highest for HePS-3 and HePS-4 and lowest for HePS-6 and HePS-7 (Fig. 5B; Supplementary Table S2). HePS-3 and HePS-4 differ from the other HePSs by containing backbone GlcNAc and GalNAc residues, respectively (Fig. 1), which may impose higher binding energy than regular sugar residues, as further supported by comparing $K_{\mathrm{A} \text {,app,repeat }}$ for HePS-4 and HePS-7, having similar repeat structures both containing $3: 1 \quad 1 \rightarrow 3: 1 \rightarrow 6$ (branch) linkages combined with compositions of 1:2:1 Glc:Gal:GalNAc and 2:2 Glc:Gal, respectively (Fig. 1). Highest apparent affinity for the four protein surfaces was seen with HePS-4 and the lowest with HePS-7, suggesting GalNAc has a positive effect on the interaction. However, avidity effects due to large differences in molar mass probably also influence the difference in $K_{\mathrm{A} \text {,app,repeat }}$ between HePS-4 and HePS-7. Notably, HePS-3 and HePS-7 had

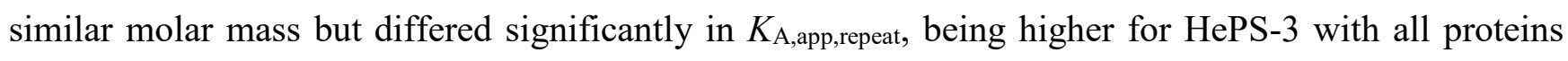
(Fig. 5B; Supplementary Table S2). Thus, different repeat unit structures were demonstrated to result in different $K_{\mathrm{A} \text {,app,repeat. }} K_{\mathrm{A} \text {,app,repeat }}$ of HePS-6 was generally low, except for $\mathrm{KCN}$ and hBLG at pH 4.0 (Fig. 5B; Supplementary Table S2). The rhamnose-rich HePS-6 repeat (4:2:1:1 Rha:Glc:Gal:pyruvate) 
may have low affinity, as this 6-deoxyhexose can form one hydrogen bond less than regular hexoses. A potential negative charge from the pyruvate in HePS-6 (Fig. 1) may also affect binding.

HePS-2 had medium affinity for the four protein surfaces, except $\mathrm{KCN}$ at $\mathrm{pH} 5.0$ and $\mathrm{nBLG}$ at $\mathrm{pH}$ 4.0, where saturation was not achieved, indicative of low affinity (Fig. 5B; Supplementary Table S2). Furthermore, no interaction was detected with nBLG at $\mathrm{pH}$ 4.5-5.0. The HePS-2 repeat unit of seven sugar residues (5:1:1 Gal:Glc:Rha) includes three branches assumed to cause substantial chain stiffness that may lead to lower binding compared to less branched HePSs (Fig. 1). HePS-1 and HePS-5 had very similar molar mass, linkage type, monosaccharide configuration, and number of branches and also gave similar $K_{\mathrm{A}, \text { app,repeat }}$ with all four proteins (Fig. 5B; Supplementary Table S2).

As seen with regard to binding capacity, affinity of hBLG and nBLG differed remarkably with all HePSs (Fig. 5A-B; Supplementary Table S2). HePS-1 and HePS-3 showed 5-7-fold higher $K_{\mathrm{A} \text {,app }}$ for nBLG than for hBLG, while HePS-4 and HePS-5 showed 2-5-fold higher $K_{\mathrm{A} \text {,app }}$ for nBLG (Fig. 5C-D; Supplementary Table S2). By contrast, HePS-6 and HePS-7 had 7-9-fold higher $K_{\text {A,app }}$ for hBLG as compared to nBLG. The difference in binding properties probably results from the conformational change of BLG induced by heat treatment (Moro et al., 2011). Furthermore, increase of $K_{\mathrm{A} \text {,app,repeat was }}$ observed with increasing $\mathrm{pH}$ as before for all four protein surfaces for HePS-1 and HePS-3-HePS-5, except for HeSP-3-nBLG and HePS-4-nBLG and HePS-5-hBLG, while binding capacity of the proteins decreased in the same $\mathrm{pH}$ range (Fig. 5A-B; Supplementary Table S2). Thus, a simple correlation was not observed between binding capacity and apparent affinity within the $\mathrm{pH}$ range 4.0-5.0, which emphasized the importance of ability to determine both $\mathrm{RU}_{\max }$ and $K_{A \text {,app }}$ of HePSprotein interactions by this SPR procedure. 
Overall, the outcome of the present study presumably reflects that structural determinants of repeat units elicit variation in HePS functionality. Usually, $\alpha$-linkages are more flexible than $\beta$-linkages (Laws et al., 2001), furanose confers higher flexibility than pyranose residues (Seo et al., 2008), while branches reduce flexibility (Tuinier et al., 2001). The diversity in HePS linkage type, monosaccharide ring configuration, and degree of branching thus invokes considerable span of HePS flexibility. This in turn has direct implication for manufacture of fermented dairy products where the milk is severely heat treated (i.e. at $90-95^{\circ} \mathrm{C}$ for several minutes) prior to fermentation in order to ensure better texture as a consequence of disulfide interactions between BLG and $\mathrm{KCN}$ on the surface of the casein micelles as well as in the serum phase (Donato \& Guyomarc'h, 2009). Subsequent production of HePS by the starter culture used during fermentation will then further influence texture through potential interaction (aggregative or segregative) with the milk proteins (van de Velde, de Hoog, Oosterveld, \& Tromp, 2015). These authors have also noted that molecular weight, linkage type, and charge of HePS are the main factors determining their effect on structure. From the present results, it would appear that a viable strategy to control texture in fermented dairy products could be to characterize starter cultures in terms of the parameters inducing flexibility and the charge density of the HePS produced in order to maximize binding affinity. This, however, has to be complemented with textural and microstructural characterization on actual dairy products and verified with a larger set of samples.

\section{Conclusions}

The established SPR protocol provides a tool for screening and validating HePS-milk protein interactions by steady-state analysis of the maximum binding capacity $\mathrm{RU}_{\max }$ and the apparent association constants $K_{\mathrm{A} \text {,app }}$ and $K_{\mathrm{A} \text {,app,repeat. }}$. The procedure is sensitive, uses a small amount of HePS for 
full binding analysis, and is applicable in evaluating both food and non-food protein-polysaccharide interactions. To our knowledge, this is the first study where comparative HePS-milk protein binding affinities have been reported. The effects of $\mathrm{pH}$, ionic strength, and temperature changes suggest HePS-protein complex formation to be driven mainly by polar interactions. Heat treatment $\left(85^{\circ} \mathrm{C} / 15\right.$ min) of BLG dramatically increased its HePS binding capacity but reduced the affinity. Even though differences in binding properties were not assigned to specific chemical properties of HePSs, the data support that both molar mass and oligosaccharide repeat structure are important for complexation as measured by maximum binding capacity $\mathrm{RU}_{\max }$ and apparent association constants $K_{\mathrm{A} \text {,app }}$ and $K_{\mathrm{A} \text {,app,repeat. }}$

\section{Acknowledgements}

Karina Jansen, Nancy Guertin, and Fleur Gagnon are thanked for skilled technical assistance. We are particularly grateful for stimulating discussion with Dr. Serge Perez. This study was funded by the Danish Research Council for Independent Research | Technology and Production Sciences and a joint PhD stipend (to JB) from the Technical University of Denmark (DTU). The Biacore T100 was granted by the Danish Research Council for Independent Research | Natural Sciences.

\section{References}

Ayala-Hernández, I., Hassan, A., Goff, H. D., Mira de Orduña, R., \& Corredig, M. (2008). Production, isolation and characterization of exopolysaccharides produced by Lactococcus lactis subsp. cremoris JFR1 and their interaction with milk proteins: Effect of $\mathrm{pH}$ and media composition. International Dairy Journal, 18(12), 1109-1118.

Babol, L. N., Svensson, B., \& Ipsen, R. (2011). Using surface plasmon resonance technology to screen 
interactions between exopolysaccharides and milk proteins. Food Biophysics, 6, 468-473.

Bai, Y., \& Yoshida, T. (2013). Separation of lacquer polysaccharides and interaction with poly-Llysine. Carbohydrate Polymers, 98(1), 270-275.

Baldini, G., Beretta, S., Chirico, G., Franz, H., Maccioni, E., Mariani, P., \& Spinozzi, F. (1999). Saltinduced association of $\beta$-lactoglobulin by light and X-ray scattering. Macromolecules, 32(19), 6128-6138.

Bleau, C., Monges, A., Rashidan, K., Laverdure, J.-P., Lacroix, M., Van Calsteren, M.-R., ... Lamontagne, L. (2010). Intermediate chains of exopolysaccharides from Lactobacillus rhamnosus RW-9595M increase IL-10 production by macrophages. Journal of Applied Microbiology, 108(2), $666-75$.

Bouzar, F., Cerning, J., \& Desmazeaud, M. (1996). Exopolysaccharide Production in Milk by Lactobacillus delbrueckii ssp. bulgaricus CNRZ 1187 and by Two Colonial Variants. Journal of Dairy Science, 79(2), 205-211.

Broadbent, J. R., McMahon, D. J., Welker, D. L., Oberg, C. J., \& Moineau, S. (2003). Biochemistry, genetics, and applications of exopolysaccharide production in Streptococcus thermophilus: a review. Journal of Dairy Science, 86(2), 407-423.

Cerning, J., Bouillanne, C., Landon, M., \& Desmazeaud, M. (1992). Isolation and characterization of exopolysaccharides from slime-forming mesophilic lactic acid bacteria. Journal of Dairy Science, 75(3), 692-699.

Chabot, S., Yu, H.-L., De Léséleuc, L., Cloutier, D., Van Calsteren, M.-R., Lessard, M., ... Oth, D. (2001). Exopolysaccharides from Lactobacillus rhamnosus RW-9595M stimulate TNF, IL-6 and IL-12 in human and mouse cultured immunocompetent cells, and IFN- $\gamma$ in mouse splenocytes. Le Lait, 81(6), 683-697. 
De Vuyst, L., De Vin, F., Vaningelgem, F., \& Degeest, B. (2001). Recent developments in the biosynthesis and applications of heteropolysaccharides from lactic acid bacteria. International Dairy Journal, 11(9), 687-707.

De Vuyst, L., \& Degeest, B. (1999). Heteropolysaccharides from lactic acid bacteria. FEMS Microbiology Reviews, 23(2), 153-177.

De Vuyst, L., Zamfir, M., Mozzi, F., Adriany, T., Marshall, V., Degeest, B., \& Vaningelgem, F. (2003). Exopolysaccharide-producing Streptococcus thermophilus strains as functional starter cultures in the production of fermented milks. International Dairy Journal, 13(8), 707-717.

Degeest, B., Mozzi, F., \& De Vuyst, L. (2002). Effect of medium composition and temperature and pH changes on exopolysaccharide yields and stability during Streptococcus thermophilus LY03 fermentations. International Journal of Food Microbiology, 79(3), 161-74.

Degeest, B., \& Vaningelgem, F. (2001). UDP-N-acetylglucosamine 4-epimerase activity indicates the presence of N-acetylgalactosamine in exopolysaccharides of Streptococcus thermophilus strains. Applied and Environmental Microbiology, 67(9), 3976-3984.

Diemer, S. K., Svensson, B., Babol, L. N., Cockburn, D., Grijpstra, P., Dijkhuizen, L., ... Ipsen, R. H. (2012). Binding interactions between $\alpha$-glucans from Lactobacillus reuteri and milk proteins characterised by surface plasmon resonance. Food Biophysics, 7(3), 220-226.

Doleyres, Y., Schaub, L., \& Lacroix, C. (2005). Comparison of the functionality of exopolysaccharides produced in situ or added as bioingredients on yogurt properties. Journal of Dairy Science, 88(12), $4146-4156$.

Donato, L., \& Guyomarc'h, F. (2009). Formation and properties of the whey protein/kappa-casein complexes in heated skim milk - A review. Dairy Science \& Technology, 89(1), 3-29.

Donot, F., Fontana, A., Baccou, J. C., \& Schorr-Galindo, S. (2012). Microbial exopolysaccharides: 
Main examples of synthesis, excretion, genetics and extraction. Carbohydrate Polymers, 87(2), $951-962$.

Dubois, M., Gilles, K. A., Hamilton, J. K., Rebers, P. A., \& Smith, F. (1956). Colorimetric method for determination of sugars and related substances. Analytical Chemistry, 28(3), 350-356.

Faber, E. J., Kamerling, J. P., \& Vliegenthart, J. F. (2001). Structure of the extracellular polysaccharide produced by Lactobacillus delbrueckii subsp. bulgaricus 291. Carbohydrate Research, 331(2), $183-94$.

Feng, M., Chen, X., Li, C., Nurgul, R., \& Dong, M. (2012). Isolation and identification of an exopolysaccharide-producing lactic acid bacterium strain from Chinese Paocai and biosorption of $\mathrm{Pb}(\mathrm{II})$ by its exopolysaccharide. Journal of Food Science, 77(6), T111-T117.

Folkenberg, D. M., Dejmek, P., Skriver, A., \& Ipsen, R. (2005). Relation between sensory texture properties and exopolysaccharide distribution in set and in stirred yoghurts produced with different starter cultures. Journal of Texture Studies, 36(2), 174-189.

Folkenberg, D. M., Dejmek, P., Skriver, A., \& Ipsen, R. (2006). Interactions between EPS-producing Streptococcus thermophilus strains in mixed yoghurt cultures. The Journal of Dairy Research, 73(4), 385-393.

Freitas, F., Alves, V. D., \& Reis, M. A. M. (2011). Advances in bacterial exopolysaccharides: from production to biotechnological applications. Trends in Biotechnology, 29(8), 388-398.

Gasteiger, E., Hoogland, C., Gattiker, A., Duvaud, S., Wilkins, M. R., Appel, R. D., \& Bairoch, A. (2005). Protein identification and analysis tools on the ExPASy server. (J. M. Walker, Ed.)The Proteomics Protocols Handbook. Humana Press Inc., Totowa, NJ.

Gruter, M., Leeflang, B. R., Kuiper, J., Kamerling, J. P., \& Vliegenthart, J. F. (1993). Structural characterisation of the exopolysaccharide produced by Lactobacillus delbrückii subspecies 
bulgaricus $\mathrm{rr}$ grown in skimmed milk. Carbohydrate Research, 239, 209-226.

Gruter, M., Leeflang, B. R., Kuiper, J., Kamerling, J. P., \& Vliegenthart, J. F. G. (1992). Structure of the exopolysaccharide produced by Lactococcus lactis subspecies cremoris $\mathrm{H} 414$ grown in a defined medium or skimmed milk. Carbohydrate Research, 231, 273-291.

Hidalgo-Cantabrana, C., López, P., Gueimonde, M., de los Reyes-Gavilán, C. G., Suárez, A., Margolles, A., \& Ruas-Madiedo, P. (2012). Immune modulation capability of exopolysaccharides synthesised by lactic acid bacteria and bifidobacteria. Probiotics and Antimicrobial Proteins, 4(4), $227-237$.

Hidalgo-Cantabrana, C., Sánchez, B., Milani, C., Ventura, M., Margolles, A., \& Ruas-Madiedo, P. (2014). Genomic overview and biological functions of exopolysaccharide biosynthesis in Bifidobacterium spp. Applied and Environmental Microbiology, 80(1), 9-18.

Kimmel, S. a, Roberts, R. F., \& Ziegler, G. R. (1998). Optimization of exopolysaccharide production by Lactobacillus delbrueckii subsp. bulgaricus RR grown in a semidefined medium. Applied and Environmental Microbiology, 64(2), 659-64.

Landersjö, C., Yang, Z., Huttunen, E., \& Widmalm, G. (2002). Structural studies of the exopolysaccharide produced by Lactobacillus rhamnosus strain GG (ATCC 53103). Biomacromolecules, 3(4), 880-884.

Laws, A., Gu, Y., \& Marshall, V. (2001). Biosynthesis, characterisation, and design of bacterial exopolysaccharides from lactic acid bacteria. Biotechnology Advances, 19(8), 597-625.

Lebeer, S., Claes, I. J. J., Verhoeven, T. L. A., Vanderleyden, J., \& De Keersmaecker, S. C. J. (2011). Exopolysaccharides of Lactobacillus rhamnosus GG form a protective shield against innate immune factors in the intestine. Microbial Biotechnology, 4(3), 368-374.

Lemoine, J., Chirat, F., Wieruszeski, J. M., Strecker, G., Favre, N., \& Neeser, J. R. (1997). Structural 
characterization of the exocellular polysaccharides produced by Streptococcus thermophilus SFi39 and SFi12. Applied and Environmental Microbiology, 63(9), 3512-3518.

Leroy, F., \& De Vuyst, L. (2004). Lactic acid bacteria as functional starter cultures for the food fermentation industry. Trends in Food Science and Technology, 15(2), 67-78.

Mende, S., Rohm, H., \& Jaros, D. (2015). Influence of exopolysaccharides on the structure, texture, stability and sensory properties of yoghurt and related products. International Dairy Journal, 52, $57-71$.

Mercadante, D., Melton, L. D., Norris, G. E., Loo, T. S., Williams, M. A. K., Dobson, R. C. J., \& Jameson, G. B. (2012). Bovine $\beta$-lactoglobulin is dimeric under imitative physiological conditions: dissociation equilibrium and rate constants over the $\mathrm{pH}$ range of 2.5-7.5. Biophysical Journal, 103(2), 303-312.

Monsan, P., Bozonnet, S., \& Albenne, C. (2001). Homopolysaccharides from lactic acid bacteria. International Dairy Journal, 11, 675-685.

Moro, A., Báez, G. D., Busti, P. A., Ballerini, G. A., \& Delorenzi, N. J. (2011). Effects of heat-treated $\beta$-lactoglobulin and its aggregates on foaming properties. Food Hydrocolloids, 25(5), 1009-1015.

Myszka, D. G. (1997). Kinetic analysis of macromolecular interactions using surface plasmon resonance biosensors. Current Opinion in Biotechnology, 8, 50-57.

Myszka, D. G. (2000). Kinetic, equilibrium, and thermodynamic analysis of macromolecular interactions with BIACORE. Methods in Enzymology, 323, 325-340.

Myszka, D. G., \& Morton, T. A. (1998). Kinetic analysis of macromolecular interactions using surface plasmon resonance biosensors. Methods in Enzymology, 295, 268-294.

Nakajima, H., Hirota, T., Toba, T., Itoh, T., \& Adachi, S. (1992). Structure of the extracellular polysaccharide from slime-forming Lactococcus lactis subsp. cremoris SBT 0495. Carbohydrate 
Research, 224, 245-253.

O'Shannessy, D. J., Brighamburke, M., Soneson, K. K., Hensley, P., \& Brooks, I. (1993).

Determination of rate and equilibrium binding constants for macromolecular interactions using surface plasmon resonance: use of nonlinear least squares analysis. Analytical Biochemistry, $212(2), 457-468$.

Patten, D. A., \& Laws, A. P. (2015). Lactobacillus-produced exopolysaccharides and their potential health benefits: a review. Beneficial Microbes, 6(4), 1-15.

Robitaille, G., Tremblay, a, Moineau, S., St-Gelais, D., Vadeboncoeur, C., \& Britten, M. (2009). Fatfree yogurt made using a galactose-positive exopolysaccharide-producing recombinant strain of Streptococcus thermophilus. Journal of Dairy Science, 92(2), 477-82. http://doi.org/10.3168/jds.2008-1312

Sakurai, K., Konuma, T., Yagi, M., \& Goto, Y. (2009). Structural dynamics and folding of $\beta$ lactoglobulin probed by heteronuclear NMR. Biochimica et Biophysica Acta, 1790(6), 527-537.

Schmid, J., Sieber, V., \& Rehm, B. (2015). Bacterial exopolysaccharides: biosynthesis pathways and engineering strategies. Frontiers in Microbiology, 6, 1-24.

Seo, M., Castillo, N., Ganzynkowicz, R., Daniels, C. R., Woods, R. J., Lowary, T. L., \& Roy, P. N. (2008). Approach for the simulation and modeling of flexible rings: Application to the $\alpha-\mathrm{D}-$ arabinofuranoside ring, a key constituent of polysaccharides from Mycobacterium tuberculosis. Journal of Chemical Theory and Computation, 4(1), 184-191.

Sheppard, D. C., \& Howell, P. L. (2016). Biofilm exopolysaccharides of pathogenic fungi: lessons from bacteria. Journal of Biological Chemistry, 291(24).

Sutherland, I. W. (2001). Biofilm exopolysaccharides: A strong and sticky framework. Microbiology, 147(1), 3-9. 
Tok, E., \& Aslim, B. (2010). Cholesterol removal by some lactic acid bacteria that can be used as probiotic. Microbiology and Immunology, 54(5), 257-264.

Torino, M. I., Font de Valdez, G., \& Mozzi, F. (2015). Biopolymers from lactic acid bacteria. Novel applications in foods and beverages. Frontiers in Microbiology, 6(September), 834.

Tsuda, H., Hara, K., \& Miyamoto, T. (2008). Binding of mutagens to exopolysaccharide produced by Lactobacillus plantarum mutant strain 301102S. Journal of Dairy Science, 91(8), 2960-2966.

Tuinier, R., van Casteren, W. H. M., Looijesteijn, P. J., Schols, H. A., Voragen, A. G. J., \& Zoon, P. (2001). Effects of structural modifications on some physical characteristics of exopolysaccharides from Lactococcus lactis. Biopolymers, 59(3), 160-166.

Van Calsteren, M.-R., Gagnon, F., Nishimura, J., \& Makino, S. (2015). Structure determination of the neutral exopolysaccharide produced by Lactobacillus delbrueckii subsp. bulgaricus OLL1073R-1. Carbohydrate Research, 413, 115-122.

Van Calsteren, M.-R., Pau-Roblot, C., Bégin, A., \& Roy, D. (2002). Structure determination of the exopolysaccharide produced by Lactobacillus rhamnosus strains RW-9595M and R. Biochemical Journal, 363, 7-17.

van de Velde, F., de Hoog, E. H. A., Oosterveld, A., \& Tromp, R. H. (2015). Protein-Polysaccharide Interactions to Alter Texture. Annual Review of Food Science and Technology, 6(1), 371-388.

van den Berg, D. J. C., Robijn, G. W., Janssen, A. C., Giuseppin, M. L. F., Vreeker, R., Kamerling, J. P., ... Verrips, C. T. (1995). Production of a novel extracellular polysaccharide by Lactobacillus sake 0-1 and characterization of the polysaccharide. Applied and Environmental Microbiology, 61(8), 2840-2844.

van Kranenburg, R., Vos, H. R., van Swam, I. I., Kleerebezem, M., \& de Vos, W. M. (1999). Functional analysis of glycosyltransferase genes from Lactococcus lactis and other gram-positive 
cocci: complementation, expression, and diversity. Journal of Bacteriology, 181(11), 6347-6353.

Vanderhoof, J. a, Whitney, D. B., Antonson, D. L., Hanner, T. L., Lupo, J. V, \& Young, R. J. (1999). Lactobacillus GG in the prevention of antibiotic-associated diarrhea in children. The Journal of Pediatrics, 135(5), 564-568.

Verheul, M. (1998). Kinetics of heat-induced aggregation of $\beta$-lactoglobulin. Journal of Agricultural and Food Chemistry, 8561(97), 896-903.

Wang, K., Li, W., Rui, X., Chen, X., Jiang, M., \& Dong, M. (2014). Characterization of a novel exopolysaccharide with antitumor activity from Lactobacillus plantarum 70810. International Journal of Biological Macromolecules, 63, 133-139.

Zannini, E., Waters, D. M., Coffey, A., \& Arendt, E. K. (2015). Production, properties, and industrial food application of lactic acid bacteria-derived exopolysaccharides. Applied Microbiology and Biotechnology, 100(3), 1121-1135.

Zhang, L., Liu, C., Li, D., Zhao, Y., Zhang, X., Zeng, X., ... Li, S. (2013). Antioxidant activity of an exopolysaccharide isolated from Lactobacillus plantarum C88. International Journal of Biological Macromolecules, 54(1), 270-275. 